\title{
Uniwersytecki System Obsługi Studiów (USOS) jako platforma prezentacii oferty dydaktycznej uczelni wyższej na przykładzie Uniwersytetu Mikołaja Kopernika w Toruniu
}

\section{System USOS - podstawowe informacje}

U niwersytecki System Obsługi Studiów (dalej: USOS), kompleksowy system obejmujący wszystkie aspekty procesu dydaktycznego i toku studiów w szkole wyższej, rozwijany jest na polskich uczelniach od $2000 \mathrm{r}$. Nadzór nad projektem sprawuje Komisja ds. USOS, w której obecnie zasiadają przedstawiciele 28 uczelni uczestniczących w projekcie. Właścicielem systemu jest Międzyuniwersyteckie Centrum Informatyzacji, jednostka powołana przez Konferencję Rektorów Akademickich Szkół Polskich „W celu tworzenia, utrzymywania i rozwijania systemów informatycznych wspierających zarządzanie uczelnią, serwisowania systemów informatycznych, szkolenia uczelnianych administratorów informatycznych oraz koordynowania wydzielonych zadań z zakresu informatyzacji uczelni" ${ }^{1}$.

Uniwersytet Mikołaja Kopernika w Toruniu (dalej: UMK) uczestniczy w projekcie współtworzenia systemu USOS od samego początku. W lip-

* Uczestniczka studiów doktoranckich z zakresu bibliologii, prowadzonych na Wydziale Nauk Historycznych Uniwersytetu Mikołaja Kopernika w Toruniu.

1 Międzyuniwersyteckie Centrum Informatyzacji [on-line] [dostęp 28 lutego 2009]. Dostępny w World Wide Web: http://www.muci.amu.edu.pl/. 
cu 2003 r. rozpoczęto implementację systemu na poszczególnych wydziałach Uniwersytetu. Obecnie objęte są nim wszystkie wydziały oraz inne jednostki dydaktyczne uczelni. Stan jego wdrożenia na UMK z podziałem według obsługi systemów studiów (poszczególne systemy studiów) oraz według funkcjonalności (poszczególne moduły) można śledzić na stronie internetowej Uniwersytetu². Ponieważ USOS podlega ciągłej aktualizacji, poniżej zaprezentowana analiza dotyczy dystrybucji 3.11.

\section{Platforma internetowa USOSweb Uniwersytetu Mikołaja Kopernika w Toruniu}

$\bigcup_{k}^{\mathrm{sis}}$ SOS należy do kategorii ewidencyjnych systemów informatycznych, których przeznaczeniem jest kompleksowa obsługa programów studiów, studentów, doktorantów, słuchaczy studiów podyplomowych i pracowników naukowo-dydaktycznych. Jego cechą charakterystyczną jest wykorzystanie centralnej bazy danych oraz modułowość poszczególnych elementów. System pracuje pod kontrolą serwera bazy danych firmy Oracle, a jego internetową platformą jest aplikacja o nazwie USOSweb $^{3}$.

Na Uniwersytecie Mikołaja Kopernika USOSweb dostępny jest na stronie domowej uczelni, pod adresem https://usosweb.umk.pl. Wgląd do większości jego zasobów mają wyłącznie użytkownicy posiadający konta pocztowe na serwerach uniwersyteckich, a więc studenci oraz pracownicy naukowo-dydaktyczni. Zalogowanie do systemu następuje poprzez centralny punkt logowania.

Interfejs użytkownika w USOSweb jest przejrzysty i niezbyt skomplikowany (rysunek 1). Niezależnie od tego, czy dostęp do niego wymaga zalogowania, czy nie, składa się on z czterech podstawowych części:

1. panel centralnego punktu logowania,

2. menu główne (wraz z nazwami kategorii, w których zebrane są

2 System USOS. Stan wdrożenia na dzień 30.11.2008 [on-line]. Uniwersytet Mikołaja Kopernika w Toruniu [dostęp 28 lutego 2009]. Dostępny w World Wide Web: http:// www.umk.pl/usos/wdrozenie.

${ }^{3}$ M. Czerniak, J. Mincer-Daszkiewicz, Uniwersytecki System Obsługi Studiów. Wstęp do dokumentacji wdrożeniowej [on-line]. Wydział Matematyki, Informatyki i Mechaniki Uniwersytetu Warszawskiego - USOS [dostęp 28 lutego 2009]. Dostępny w World Wide Web: http://www.usos.edu.pl/InstrukcjaWdrozenia/Wdrozenie2008-12-06.pdf. 
najważniejsze dla danej grupy użytkowników moduły, np. „Dla studentów”, „Dla pracowników”),

3. menu podrzędne (panel boczny, zawierający menu związane z pozycją wybraną z menu głównego),

4. treść strony.

Dodatkowo w prawym górnym rogu ekranu umieszczono podstawowe informacje o możliwościach systemu i pliki pomocy z materiałami ułatwiającymi korzystanie z jego zasobów.

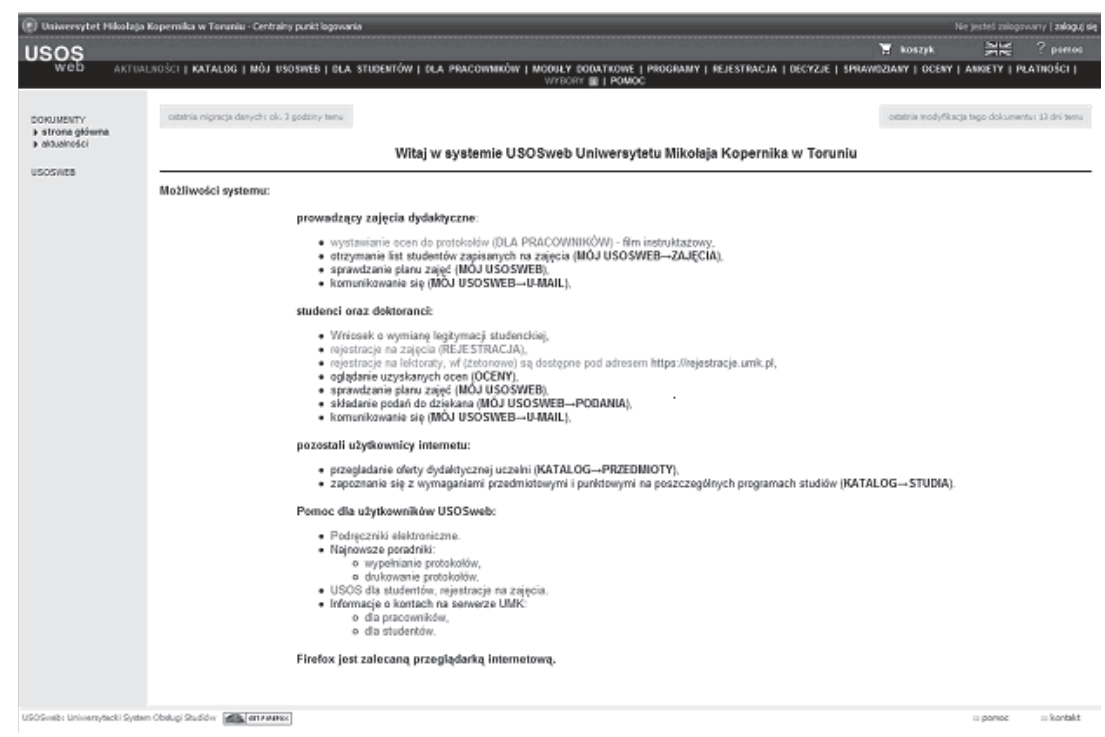

Rysunek 1. Ekran powitalny systemu USOSweb UMK

Źródło: USOSweb UMK [on-line]. Uniwersytet Mikołaja Kopernika w Toruniu [dostęp 28 lutego 2009]. Dostępny w World Wide Web: https://usosweb.umk.pl/ kontroler.php?_action=actionx:news/local().

Aplikacja internetowa USOSweb pozwala na przeniesienie wielu czynności i procedur wykonywanych przez pracowników i studentów, które są związane z organizacją i dokumentacją przebiegu studiów na płaszczyznę elektroniczną ${ }^{4}$.Za pomocą USOSweb studenci UMK mogą zapisywać się na zajęcia, uzyskiwać informacje o ocenach z egzaminów i zaliczeń, płatnościach za usługi edukacyjne, przyznanych stypendiach, wymaganiach pro-

${ }^{4}$ M. Czerniak, Sieć bez tajemnic. USOS - Uniwersytecki System Obsługi Studiów [on-line]. Uniwersytet Mikołaja Kopernika w Toruniu [dostęp 28 lutego 2009]. Dostępny w World Wide Web: http://www.umk.pl/uslugi-informatyczne/usos. 
gramowych na studiowanym kierunku, a także składać standardowe podania do dziekana czy wypełniać ankiety dotyczące procesu dydaktycznego. Pracownicy naukowo-dydaktyczni mogą natomiast wystawiać oceny i zaliczenia, wypełniając protokoły egzaminacyjne, sprawdzać swój plan zajęć oraz komunikować się za pomocą poczty elektronicznej ze studentami uczęszczającymi na prowadzone przez nich zajęcia.

Poza opcjami dostępnymi wyłącznie dla członków społeczności akademickiej UMK, posiadających konta na serwerach uczelnianych, na platformie USOSweb istnieje dodatkowo kilka modułów ogólnodostępnych, niewymagających logowania się do systemu. Są one umieszczone w tzw. „Katalogu Publicznym” (rysunek 2).

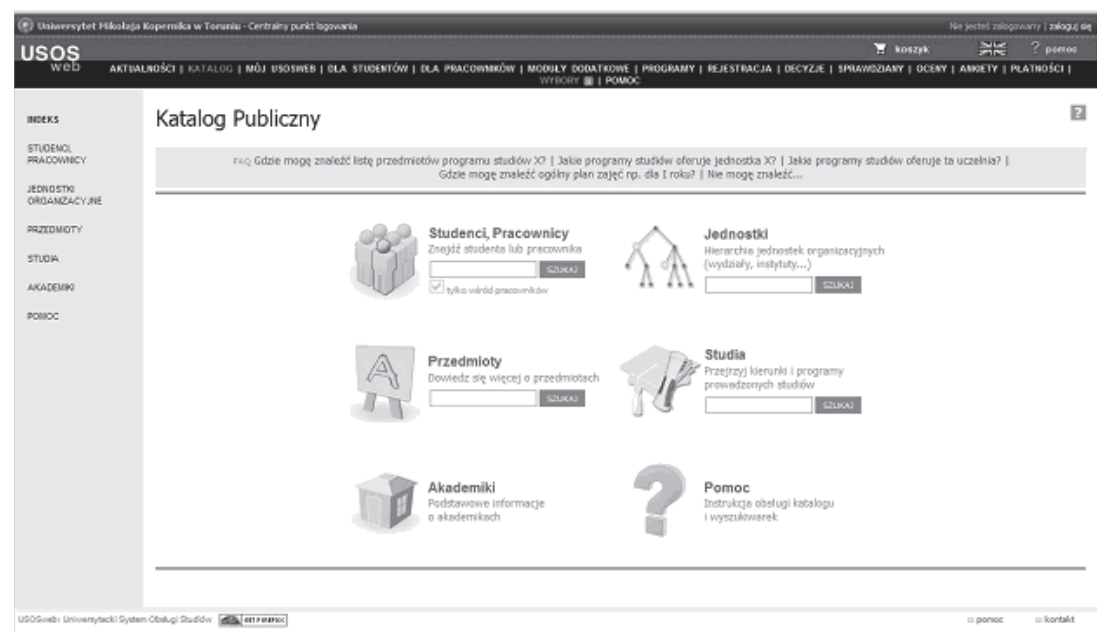

Rysunek 2. Katalog Publiczny systemu USOSweb UMK

Źródło: Katalog-Indeks [on-line]. Uniwersytet Mikołaja Kopernika w Toruniu [dostęp 28 lutego 2009]. Dostępny w World Wide Web: https://usosweb.umk.pl/ kontroler.php?_action=actionx:katalog2/index().

Za pomocą „Katalogu Publicznego” każda osoba odwiedzająca strony internetowe Uniwersytetu ma możliwość swobodnego przeglądania hierarchii jednostek organizacyjnych, kierunków i programów prowadzonych studiów, uzyskiwania podstawowych informacji o domach studenckich oraz przeszukiwania bazy pracowników uczelni. Szczególnie przydatną pozycją jest tu wyszukiwarka przedmiotów, umożliwiająca wgląd w ofertę dydaktyczną Uniwersytetu. 


\section{Moduł „Przedmioty” jako narzędzie prezentacji oferty dydaktycznej uczelni w USOSweb}

$\mathrm{N}$ a ofertę dydaktyczną Uniwersytetu Mikołaja Kopernika w Toruniu, prezentowaną w systemie USOSweb, składa się zestaw ponad 19 tys. przedmiotów, z tego ponad 7,8 tys. uruchomionych w roku akademickim $2008 / 2009^{5}$.

Tworzenie bazy przedmiotów na UMK odbywa się w sposób zdecentralizowany i ma miejsce w poszczególnych jednostkach dydaktycznych. Zadaniem tym zajmują się specjalnie wyznaczeni koordynatorzy, którym nadano uprawnienia do rozbudowy i modyfikacji modułu „Przedmioty”. Podstawowym rekordem, stanowiącym trzon omawianego modułu, jest konkretny przedmiot nauczania. Definiowany jest on za pomocą rozbudowanego zestawu pól, które w rezultacie tworzą jego ogólną charakterystykę, widoczną w USOSweb. Najważniejszymi polami pojedynczego rekordu są:

- kod przedmiotu w systemie USOS,

- kod przedmiotu w systemie kodowania programu Socrates ${ }^{6}$,

- nazwa przedmiotu,

- jednostka oferująca przedmiot,

- grupa, do której należy przedmiot,

- liczba punktów w systemie ECTS,

- język prowadzenia zajęć,

- rodzaj przedmiotu (obowiązkowy, fakultatywny) (por. rysunek 3).

Każdy przedmiot umieszczony w ofercie dydaktycznej UMK musi otrzymać unikalny i jednoznaczny kod, identyfikujący go w systemie USOS. Składa się on z dwóch części oddzielonych kreską, tj. kodu jednostki odpowiedzialnej za przedmiot (wydział, instytut, katedra) oraz kodu przedmiotu w ramach jednostki ${ }^{7}$. Zasady tworzenia kodów przedmiotów w systemie USOS regulują przepisy ogólnouniwersyteckie ${ }^{8}$.

5 System USOS...

${ }^{6}$ Do końca stycznia 2009 r. UMK nie wprowadził tego systemu kodowania.

7 Propozycja kodowania przedmiotów w systemie USOS [on-line]. Uniwersytet Mikołaja Kopernika w Toruniu [dostęp 28 lutego 2009]. Dostępny w World Wide Web: http:// www.umk.pl/usos/dokumentacja.

${ }^{8}$ Zarzadzenie Nr 31 Rektora Uniwersytetu Mikołaja Kopernika w Toruniu z dnia 23 maja 2006 r. dotyczace zmiany zarządzenia Nr 63 Rektora UMK z dnia 27 listopada 2003 r. w sprawie kodowania rodzajów i systemów studiów oraz struktury organizacyjnej Uniwer- 
Jednym z najważniejszych parametrów definiujących przedmiot jest jego nazwa. Nie musi ona być unikalna, ponieważ dana jednostka dydaktyczna może oferować kilka przedmiotów o tej samej nazwie. Mogą być one realizowane na innych poziomach i w odmiennych trybach kształcenia oraz różnić się między sobą liczbą godzin dydaktycznych, typem zajęć czy liczbą punktów ECTS. Wyszukiwanie przedmiotów według nazwy może zatem skutkować uzyskaniem listy kilku przedmiotów o tej samej nazwie.

Mianem jednostki oferującej przedmiot określa się w systemie USOS wydział lub inną samodzielną komórkę uczelnianą (np. Studium Praktycznej Nauki Języków Obcych), która umieściła dane zajęcia w swojej ofercie dydaktycznej. Poza przypisaniem przedmiotu do konkretnej jednostki konieczne jest jednak umieszczenie go także w określonej grupie przedmiotów, tak by możliwe było przeglądanie bazy pod kątem przedmiotów przewidzianych wyłącznie dla określonego kierunku studiów.

Kolejnym polem opisu jest liczba punktów ECTS, które uzyskuje student zaliczający dane zajęcia. Ponieważ w wielu przypadkach przedmiotom, posiadającym tę samą nazwę, a realizowanym na różnych poziomach kształcenia, przyporządkowano inną liczbę punktów, by ułatwić użytkownikowi orientację w ofercie dydaktycznej uczelni, stworzono odnośnik „Zobacz reguły punktacji”, gdzie może on uzyskać szczegółowe informacje na ten temat.

Większość jednostek UMK nie definiuje w USOSweb języka prowadzenia zajęć. W związku z tym można przypuszczać, że większość przedmiotów prowadzona jest po polsku. Wypełnienie pola "Język prowadzenia” byłoby jednak zasadne w przypadku zajęć realizowanych w obrębie specjalistycznych kursów, np. przeznaczonych dla studentów zagranicznych odbywających studia na UMK w ramach programów międzynarodowych.

Ostatnim podstawowym polem opisu przedmiotu jest pole „Rodzaj przedmiotu”. Określa ono, czy dla danego kierunku i poziomu studiów dany przedmiot jest obowiązkowy, fakultatywny czy uzupełniający.

Poza ogólną charakterystyką przedmiotu, zawartą w podstawowych polach rekordu, system USOSweb pozwala uzyskać także bardziej szczesytetu Mikołaja Kopernika. Biuletyn Prawny UMK [on-line] nr 4 z dnia 10 lipca 2006 r. [dostęp 28 lutego 2009]. Dostępny w World Wide Web: http://www.umk.pl/uczelnia/dokumenty/biuletyn/prawo/?akcja=dokument\&typ=Z_Rektora\&nr=31\&bp=4\&rok=2006; Załącznik do zarządzenia Nr 31 Rektora UMK z dnia 23 maja 2006 r. [on-line]. Uniwersytet Mikołaja Kopernika w Toruniu [dostęp 28 lutego 2009]. Dostępny w World Wide Web: http://www.umk.pl/usos/dokumentacja/kody_umk.pdf. 
gółowe informacje o przedmiocie w konkretnym cyklu dydaktycznym (np. w danym roku akademickim). Wśród tego typu danych wyróżnić należy okres, w którym przedmiot jest oferowany, typ zajęć, liczbę godzin dydaktycznych i limit miejsc w grupach (opcjonalnie), koordynatorów, prowadzących grupy oraz formę zaliczenia (por. rysunek 3).

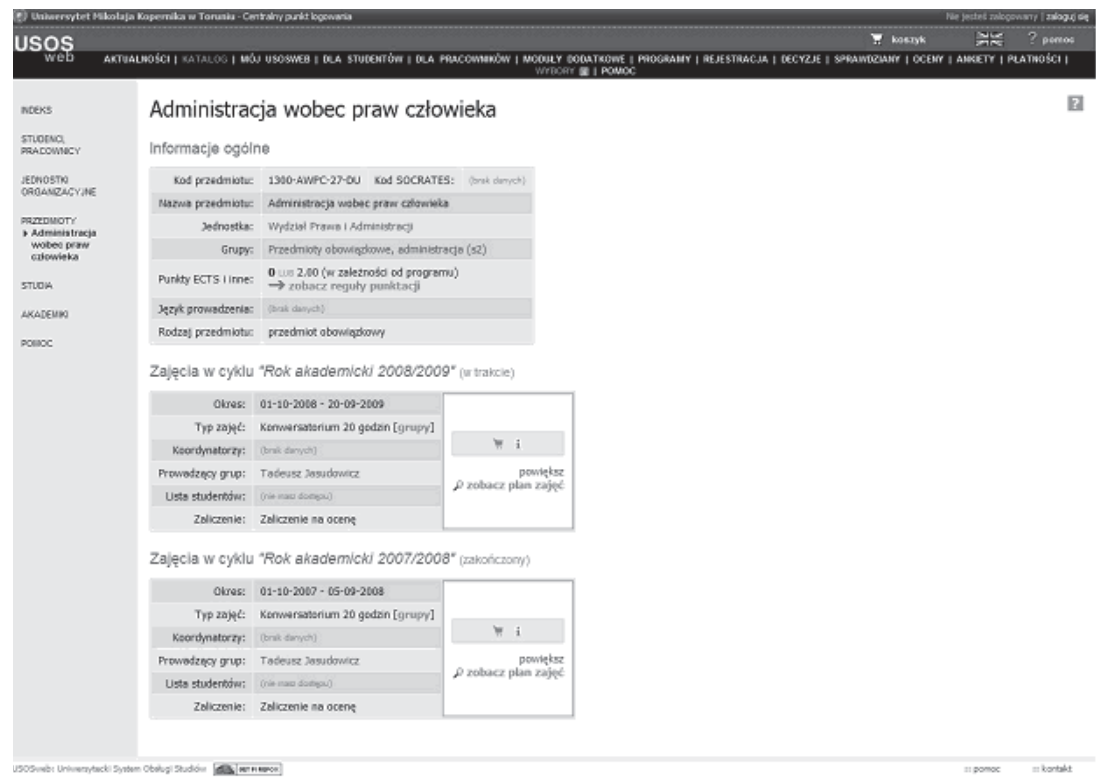

Rysunek 3. Przykładowa strona przedmiotu w USOSweb UMK

Źródło: Administracja wobec praw człowieka [on-line]. Uniwersytet Mikołaja Kopernika w Toruniu [dostęp 28 lutego 2009]. Dostępny w World Wide Web: https://usosweb.umk.pl/kontroler.php?_action=actionx:katalog2/przedmioty/ pokazPrzedmiot(prz_kod:1300-ADM.W.PR-27-DM).

Warto zauważyć, że konkretnemu przedmiotowi przypisany może być więcej niż jeden typ zajęć (np. wykład oraz ćwiczenia). Istotne wydaje się także wyróżnienie dwóch kategorii: koordynatorów i prowadzących grupy. Koordynatorzy to pracownicy naukowo-dydaktyczni, którzy odpowiadają w danej jednostce za treści kształcenia i sposób prowadzenia zajęć z danego przedmiotu. Funkcja koordynatora nie musi być jednak tożsama z funkcją prowadzącego grupy zajęciowe.

O pewnym uproszczonym rozwiązaniu trzeba z kolei pamiętać w przypadku pola „Zaliczenie”. Odzwierciedla ono bowiem jedynie domyślny typ protokołu zdefiniowany dla całości przedmiotu, co oznacza, że nie rozróż- 
nia się tu podziału form zaliczenia ze względu na typ prowadzonych zajęć (np. egzamin dla wykładu, zaliczenie na ocenę dla ćwiczeń).

Bardzo przydatną opcją na stronie przedmiotu jest funkcja „Zobacz plan zajęć", która umożliwia wyświetlenie w formie tabeli rozkładu zajęć dla poszczególnych grup z uwzględnieniem godzin i miejsca ich odbywania (budynek, sala) oraz osoby prowadzącej.

Istotnym dopełnieniem charakterystyki przedmiotu w USOSweb są pola: „Skrócony opis przedmiotu”, „Pełny opis przedmiotu” oraz „Literatura". Można w nich umieścić informacje na temat treści programowych, zagadnień poruszanych w trakcie zajęć, wymagań stawianych studentom czy zalecanej literatury. Opcje te mogą być szczególnie przydatne np. podczas wyboru przedmiotu fakultatywnego. Pomagają one także potencjalnym kandydatom na studia zorientować się w tematyce zajęć prowadzonych na danym kierunku.

\section{Wyszukiwanie przedmiotów i przeglądanie oferty dydaktycznej w module "Przedmioty"}

\footnotetext{
Wyszukiwanie przedmiotów w „Katalogu Publicznym” USOSweb może się odbywać na dwa sposoby:

- poprzez wpisanie w okno wyszukiwarki części kodu poszukiwanego przedmiotu, jego nazwy lub nazwy jednostki oferującej przedmiot,

- poprzez przeglądanie drzewa hierarchicznego jednostek organizacyjnych Uniwersytetu.

W „Katalogu Publicznym” wprowadzono mechanizm przyśpieszonego wyszukiwania, nazywany automatycznymi podpowiedziami lub selektorami ${ }^{9}$. Jest to system sugerujący użytkownikowi właściwą odpowiedź, gdy nie jest on pewien, czy wprowadzone przez niego wyrażenie wyszukiwawcze jest jednoznaczne (np. gdy nie pamięta dokładnej nazwy wyszukiwanego przedmiotu). Mechanizm generowania automatycznych podpowiedzi ilustruje rysunek 4 .
}

${ }_{9}$ Katalog - Pomoc. Automatyczne podpowiedzi (selektory) [on-line]. Uniwersytet Mikołaja Kopernika w Toruniu [dostęp 28 lutego 2009]. Dostępny w World Wide Web: https: //usosweb.umk.pl/kontroler.php?_action=actionx: katalog2/pomoc(section:selektory). 
W przypadku, gdy użytkownik nie korzysta z dostępnych selektorów, a w systemie znajduje się więcej niż jeden przedmiot zawierający wskazane wyrażenie wyszukiwawcze, zostaje wyświetlona lista wszystkich przedmiotów spełniających podane kryteria wraz z dodatkowymi informacjami. Następnie użytkownik może sam wybrać przedmiot z listy (klikając na odnośnik „Opis przedmiotu”) lub zmodyfikować zapytanie, jeśli zbiór wyników wyszukiwania jest zbyt duży.

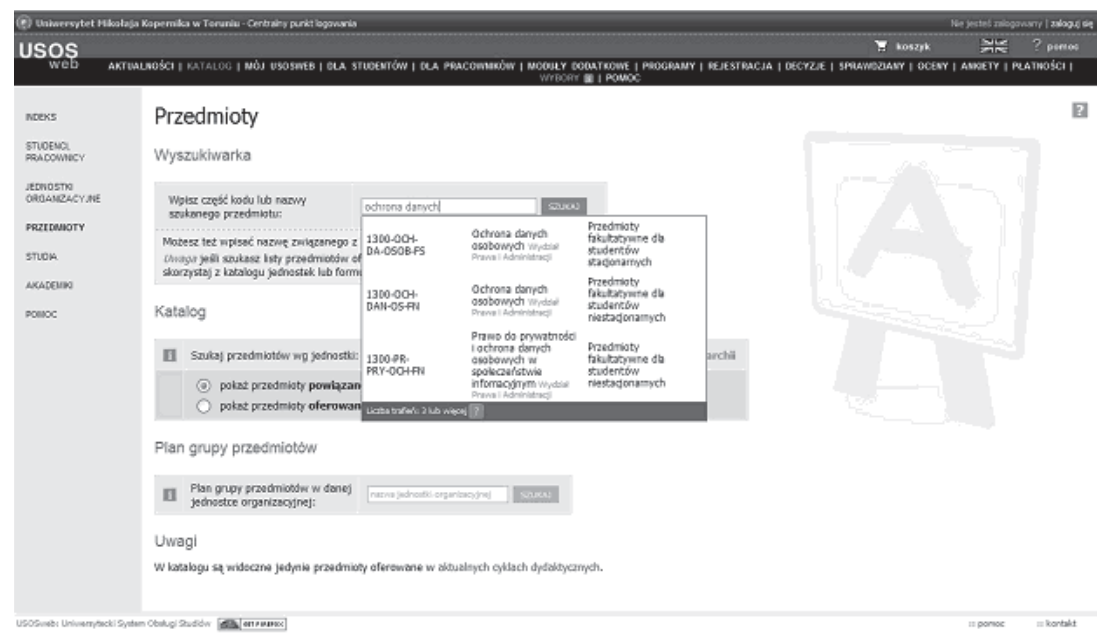

Rysunek 4. Wyszukiwarka przedmiotów z uruchomioną opcją automatycznych podpowiedzi

Źródło: Przedmioty. Wyszukiwarka [on-line]. Uniwersytet Mikołaja Kopernika w Toruniu [dostęp 28 lutego 2009]. Dostępny w World Wide Web: https://usosweb.umk.pl/kontroler.php?_action=actionx:katalog2/przedmioty/index().

W sytuacji, gdy użytkownik jest szerzej zainteresowany konkretną grupą przedmiotów (np. na danym kierunku studiów), możliwa jest zmiana ustawień strony tak, aby wyświetlane były wybrane informacje dodatkowe, np. opis skrócony przedmiotu lub tzw. koszyki rejestracyjne ${ }^{10}$.

W każdym miejscu „Katalogu Publicznego” użytkownik ma możliwość skorzystania z opcji pomocy, którą oznaczono ikoną znaku zapytania

10 Symbol koszyka oznacza, że przedmiot prowadzony jest w danym cyklu dydaktycznym, a poprzez USOSweb możliwa jest rejestracja na zajęcia dydaktyczne z jego zakresu. Dodatkowe informacje dotyczące rejestracji (np. tryb rejestracji, okres jej trwania, limit miejsc w grupach zajęciowych) można uzyskać, klikając na ikonę „i”, znajdującą się obok symbolu koszyka. 
w prawym górnym rogu ekranu (zob. rysunek 4). Zawarte w poszczególnych plikach informacje istotnie ułatwiają proces wyszukiwania przedmiotów lub przeglądania oferty dydaktycznej poszczególnych jednostek.

\section{Jakość zasobów USOSweb UMK}

Dodobnie jak w przypadku większości zasobów informacyjnych Internetu, o jakości prezentowanych na platformie USOSweb informacji decyduje ich aktualność, relewantność i kompletność.

Jak już wspomniano, tworzenie i zarządzanie zasobami oferty dydaktycznej UMK odbywa się na poziomie jednostek organizacyjnych. Pracownikom, którym powierzono te obowiązki, administratorzy programu USOS przydzielili odpowiednie uprawnienia (tzw. rolę w systemie). Do zadań koordynatorów oferty dydaktycznej w USOSweb należy utrzymywanie bazy przedmiotów własnej jednostki w taki sposób, aby zapewnić zasobom:

- aktualność - należy na bieżąco dostosowywać ofertę dydaktyczną do zmian programów studiów, treści programowych czy systemu punktacji ECTS,

- relewantność - należy starać się wykorzystywać możliwości systemu do zaspokojenia potrzeb informacyjnych potencjalnych użytkowników USOSweb,

- kompletność - należy zamieszczać możliwie pełne opisy poszczególnych przedmiotów, by w ten sposób tworzyć kompleksowy system informacji o ofercie dydaktycznej jednostki i uczelni.

Koordynatorzy oferty dydaktycznej muszą pamiętać, że wszelkie usterki natury redakcyjnej (np. błędy literowe), obok oczywistych względów estetycznych, mają swoje dalsze konsekwencje. Ponieważ baza przedmiotów jest źródłem danych również dla innych modułów USOS, błędy powstałe $\mathrm{w}$ wyniku edycji poszczególnych pól rekordu mogą skutkować ich powielaniem w wielu dokumentach urzędowych (np. wprowadzona do systemu niewłaściwa nazwa przedmiotu może pojawić się następnie na kartach egzaminacyjnych studentów lub w suplemencie do dyplomu ukończenia studiów). W celu zapewnienia spójności zasobów w skali całego Uniwersytetu koordynatorzy powinni zatem stosować się do ogólnouniwersyteckich wytycznych, przynajmniej tych dotyczących zasad kodowania przedmiotów. 


\section{Oferta dydaktyczna Uczelni w USOSweb - perspektywy rozwoju}

W chwili obecnej platforma USOSweb Uniwersytetu Mikołaja Kopernika w Toruniu (w tym moduł „Przedmioty”) wykorzystywana jest głównie przez środowisko akademickie uczelni. Studenci mają możliwość przeglądania istniejącej oferty dydaktycznej oraz weryfikacji wymagań programowych przewidzianych dla kierunku kształcenia, na który się zdecydowali. Szczegółowe opisy przedmiotów pomagają im także podjąć decyzję dotyczącą wyboru zajęć fakultatywnych.

Docelowo moduł „Przedmioty” ma również służyć użytkownikom spoza UMK, zwłaszcza kandydatom na studia, którzy poszukują kompleksowej informacji na temat prowadzonych przez uczelnię kierunków studiów i przedmiotów oferowanych w ich ramach. Szkoły wyższe wykorzystujące podczas procesu rekrutacji stowarzyszoną z USOS aplikację Internetowa Rejestracja Kandydatów zamierzają w najbliższym czasie przystąpić do współtworzenia tzw. Internetowego Katalogu Studiów. Jest to najmłodsza z aplikacji opracowywanych przez zespół tworzący system USOS, a przygotowana została w celu prezentacji oferty studiów prowadzonych przez polskie uczelnie wyższe ${ }^{11}$.

Należy mieć nadzieję, że w najbliższych latach aplikacje internetowe systemu USOS, w tym moduł „Przedmioty”, dzięki stałemu doskonaleniu i rozbudowie staną się kompleksowym i uniwersalnym źródłem informacyjnym zarówno dla środowiska akademickiego, jak i szerokiego grona innych użytkowników Internetu.

\section{University System for Studies Management (USOS) as a platform presenting courses offered by the university, based on the case of the Nicolaus Copernicus University in Torun Abstract}

University System for Studies Management (USOS) is a comprehensive system comprising all aspects of teaching and studying processes on an academic level. The Internet application of the system is called USOSweb. The application enables to present courses offered by the university within the Courses module. With the example of the USOSweb site of the Nicolaus Copernicus University in

${ }^{11}$ M. Czerniak, J. Mincer-Daszkiewicz, dz. cyt. 
Torun, methods of course description were presented. Also the browsing and searching strategies within the courses catalogue, as well as content quality procedures were explained. Special attention was paid to possible future development of the Courses module as an information resource for the academic community. 